\title{
KAJIAN PENGGUNAAN ANTIBIOTIK PENDERITA DIARE PADA PASIEN PEDIATRIK DI INSTALASI RAWAT INAP RSUD ABDUL WAHAB SJAHRANIE SAMARINDA
}

\author{
Rita Yuniati*, Nur Mita, Arsyik Ibrahim \\ ${ }^{1}$ Laboratorium Penelitian dan Pengembangan FARMAKA TROPIS \\ Fakultas Farmasi Universitas Mulawarman Samarinda Kalimantan Timur \\ *Email: ayiery17@gmail.com
}

\begin{abstract}
ABSTRAK
Diare merupakan kondisi dimana terjadi frekuensi defekasi lebih dari 3 kali sehari dengan konsistensi feses cair. Diare pada bayi dan anak-anak adalah pengeluaran tinja $>10$ $\mathrm{g} / \mathrm{kg} / 24$ jam. Antibiotik diindikasikan untuk diare yang disebabkan oleh infeksi bakteri. Penelitian ini bertujuan untuk mengetahui karakteristik serta pola penggunaan antibiotik penderita diare pada pasien pediatrik. Metode penelitian yang digunakan bersifat non eksperimental dengan pendekatan observasional secara prospektif. Data dianalisis secara deskriptif. Subjek penelitian adalah penderita diare pada pasien pediatrik yang menggunakan antibiotik sebanyak 42 pasien, yang kemudian dikarakterisasikan berdasarkan jenis kelamin, usia, pendidikan dan pekerjaan orang tua serta penggunaan antibiotik. Hasil penelitian berdasarkan karakteristik pasien yaitu laki-laki $(61,90 \%)$, perempuan $(38,10 \%)$, pendidikan dan pekerjaan orang tua yaitu SLTA $(47,62 \%)$ dan swasta $(57,14 \%)$ serta usia 1-12 tahun $(71,43 \%)$. Antibiotik yang digunakan adalah amikacin (2,13\%), ampicillin (21,27\%), cefotaxime (34,04\%), ceftriaxone $(21,27 \%)$, colistin $(2,13 \%)$, cotrimoxazole $(14,89 \%)$, meropenem $(2,13 \%)$ dan metronidazole $(2,13 \%)$. Berdasarkan hasil penelitian yang diperoleh disimpulkan bahwa penderita diare pada pasien pediatrik lebih banyak terjadi pada laki-laki dan antibiotik yang dominan digunakan sebagai terapi pengobatan diare adalah golongan cephalosphorin generasi ketiga yaitu cefotaxime.
\end{abstract}

Kata Kunci : diare, antibiotik, pediatrik

\begin{abstract}
Diarrhea is a condition in which the frequency of defecation occurs more than 3 times a day with liquid stool consistency. Diarrhea in infants and children are spending stool $>10 \mathrm{~g} / \mathrm{kg} / 24$ hours. Antibiotics are indicated for diarrhea caused by bacterial infection. This study aims to determine the characteristics and patterns of antibiotic use in pediatric patients with diarrhea. The method used is non experimental prospective observational approach. Data were analyzed descriptively. Subjects were patients with diarrhea in pediatric patients who use antibiotics for 42 patients, who were then characterized by gender, age, education and occupation of parents as well as the use of antibiotics. The results based on the characteristics of the patients are male (61,90\%), women $(38,10 \%)$, education and occupation of parents are high school $(47,62 \%)$ and private $(57,14 \%)$ and ages $1-12$ years $(71,43 \%)$. Antibiotics used were amikacin $(2,13 \%)$, ampicillin (21,27\%), cefotaxime (34.04\%), ceftriaxone (21,27\%), colistin $(2,13 \%)$,
\end{abstract}


cotrimoxazole $(14,89 \%)$, meropenem $(2,13 \%)$ and metronidazole $(2,13 \%)$. Based on the results obtained research concluded that patients with diarrhea in pediatric patients is more common in males and dominant antibiotic used for the treatment of diarrhea treatment is a class of third-generation cephalosporin that is cefotaxime.

Keywords: diarrhea, antibiotics, pediatric

\section{PENDAHULUAN}

Di seluruh dunia penyakit diare merupakan penyebab utama angka kesakitan dan kematian pada anak-anak, dengan 1,5 milyar kejadian dan diperkirakan setiap tahunnya angka kematian sebesar 1,5 sampai 2,5 juta di antara anak-anak berusia di bawah 5 tahun (Poerwati, 2013).

Diare masih menjadi masalah kesehatan masyarakat di negara berkembang termasuk di Indonesia. Diare masih merupakan penyebab kematian bayi yang terbanyak yaitu $42 \%$ dibanding pneumonia 24\%, untuk golongan 1-4 tahun penyebab kematian karena diare 25,2\% dibanding pneumonia 15,5\% (Juffrie, 2009). Menurut Dinas Kesehatan Profinsi Kalimantan Timur (2013), diare merupakan penyakit dengan kasus terbanyak dari seluruh puskesmas yang ada di Kalimantan Timur dengan jumlah 48.290 kasus, sedangkan hasil Riset Kesehatan Dasar Provinsi Kalimantan Timur (2007), diare tersebar di semua kelompok umur dengan prevalensi tertinggi terdeteksi pada umur 1-4 tahun (12,5\%) dan < 1 tahun (11,6 \%) (Departemen Kesehatan Republik Indonesia, 2009).

Diare adalah peningkatan pengeluaran tinja dengan konsistensi lebih lunak atau lebih cair dari biasanya, dan terjadi paling sedikit 3 kali dalam 24 jam. Dalam referensi lain disebutkan bahwa definisi diare untuk bayi dan anak-anak adalah pengeluaran tinja $>10$ $\mathrm{g} / \mathrm{kg} / 24 \mathrm{jam}$, sedangkan rata-rata pengeluaran tinja normal pada bayi sebesar 5-10 g/kg/24 jam. Di negara berkembang diare akut merupakan penyebab utama morbiditas dan mortalitas pada anak. Diare akut adalah buang air besar pada bayi atau anak lebih dari 3 kali perhari, disertai perubahan konsistensi tinja mejadi cair dengan atau tanpa lendir dan darah yang berlangsung kurang dari satu minggu. Terdapat banyak penyebab diare akut pada anak. Pada sebagian besar kasus penyebabnya adalah infeksi akut intestinum yang disebabkan oleh virus, bakteri atau parasit, akan tetapi berbagai penyakit lain juga dapat menyebabkan diare akut, termasuk sindroma malabsorpsi (Juffrie, 2009).

Antibiotik adalah agen yang digunakan untuk mencegah dan mengobati suatu infeksi karena bakteri. Akan tetapi, istilah antibiotik sebenarnya mengacu pada zat kimia yang dihasilkan oleh satu macam organisme, terutama fungi, yang menghambat pertumbuhan atau membunuh organisme yang lain (Neal, 2006). Berdasarkan mekanisme kerjanya terhadap bakteri, antibiotik dikelompokkan menjadi inhibitor sintesis dinding sel bakteri (golongan beta laktam seperti penisilin, sefalosporin, karbapenem, monobaktam dan antibiotik lainnya seperti vancomysin, basitrasin, fosfomysin dan daptomysin), inhibitor sintesis protein bakteri (aminoglikosida, makrolida, tetrasiklin), menghambat sintesa folat (sulfonamida dan trimetoprim), mengubah permeabilitas membran sel (polimiksin, amfoterisin B, gramisidin, nistatin, kolistin), mengganggu sintesis DNA (metronidasol, kinolon, novobiosin) dan mengganggu sintesa RNA (rifampisin) (Stringer dan Janet, 2006).

Antibiotika pada umumnya tidak diperlukan pada semua diare akut oleh karena sebagian besar diare infeksi adalah rotavirus yang sifatnya self limited dan tidak dapat dibunuh dengan antibiotika. Hanya sebagian kecil $(10-20 \%)$ yang disebabkan oleh bakteri patogen seperti V. cholera, Shigella, Enterotoksigenik E. coli, Salmonella, Camphylobacter dan sebagainya (Juffrie, 2009). Menurut Cakrawardi (2009), terapi 
antibiotik diindikasikan untuk diare yang disebabkan oleh infeksi bakteri. Walaupun pemakaian antibiotik yang baik berlaku untuk semua umur, antibiotik untuk populasi pediatrik perlu memperoleh perhatian khusus karena kecenderungan pemakaian yang berlebihan (Darmansjah, 2008). Penggunaan antibiotik yang tidak tepat dalam hal indikasi, maupun cara pemberian dapat merugikan penderita dan dapat memudahkan terjadinya resistensi terhadap antibiotik serta dapat menimbulkan efek samping. Hal-hal yang perlu diperhatikan adalah dosis obat yang tepat bagi anak-anak, cara pemberian, indikasi, kepatuhan, jangka waktu yang tepat dan dengan memperhatikan keadaan patofisiologi pasien secara tepat, diharapkan dapat memperkecil efek samping yang akan terjadi. (Rudolph, 2003).

Berdasarkan alasan-alasan tersebut maka perlu dilakukan penelitian mengenai pola penggunaan antibiotik penderita diare pada pasien pediatrik di instalasi rawat inap RSUD Abdul Wahab Sjahranie Samarinda. Tujuan dari penelitian ini adalah mengetahui karakteristik pasien pediatrik serta pola penggunaan antibiotik penderita diare pada pasien pediatrik di instalasi rawat inap RSUD Abdul Wahab Sjahranie Samarinda.

\section{METODE PENELITIAN}

Penelitian ini merupakan penelitian non eksperimental secara deskriptif dengan pendekatan observasional yang bersifat prospektif. Populasi dalam penelitian ini adalah seluruh penderita diare pada pasien pediatrik yang menggunakan antibiotik yang ada di dalam ruang rawat inap Melati di RSUD Abdul Wahab Sjahranie Samarinda. Teknik penarikan sampel yang dilakukan berdasarkan karakteristik atau kriteria tertentu yang telah ditetapkan oleh peneliti. Sampel kemudian di karakteristikan berdasarkan jenis kelamin, usia, pekerjaan dan pendidikan orang tua serta pola penggunaan antibiotik. Data yang diperoleh dari karakteristik pasien selanjutnya dianalisis secara deskriptif dan diolah menjadi bentuk persentase serta disajikan dalam bentuk tabel atau diagram.

\section{HASIL DAN PEMBAHASAN}

Penelitian ini di lakukan di instalasi rawat inap Melati di RSUD Abdul Wahab Sjahranie Samarinda pada bulan Desember 2015 sampai Maret 2016 dengan mengumpulkan data rekamedik penderita diare pada pasien pediatrik sebagai populasi penelitian. Sampel yang digunakan adalah penderita diare pada pasien pediatrik yang menggunakan antibiotik dengan jumlah pasien sebanyak 42 pasien. Kemudian pasien dikarakterisasi berdasarkan jenis kelamin, usia, pendidikan orang tua dan pekerjaan orang tua. Hasil yang diperoleh dari data penderita diare pada pasien pediatrik yang menggunakan antibiotik di ruang rawat inap Melati adalah sebanyak $26(61,90 \%)$ pasien berjenis kelamin laki-laki dan $16(38,10 \%)$ pasien berjenis kelamin perempuan (Tabel 1).

Tabel 1. Distribusi Jenis Kelamin Penderita Diare Pada Pasien Pediatrik yang Menggunakan Antibiotik di Instalasi Rawat Inap RSUD Abdul Wahab Sjahranie Samarinda

\begin{tabular}{ccc}
\hline Jenis Kelamin & Jumlah & Presentase \\
\hline Laki-laki & 26 & $61,90 \%$ \\
Perempuan & 16 & $38,10 \%$ \\
\hline Total & $\mathbf{4 2}$ & $\mathbf{1 0 0 \%}$ \\
\hline
\end{tabular}

Pasien anak laki-laki lebih banyak yang mengalami diare daripada pasien anak perempuan. Hal ini kemungkinan disebabkan karena pasien anak laki-laki kurang 
memperhatikan kebersihan diri dan lingkungannya daripada anak perempuan. Dengan demikian mengakibatkan anak laik-laki sering terkena diare dibandingkan anak perempuan (Smith, 2003).

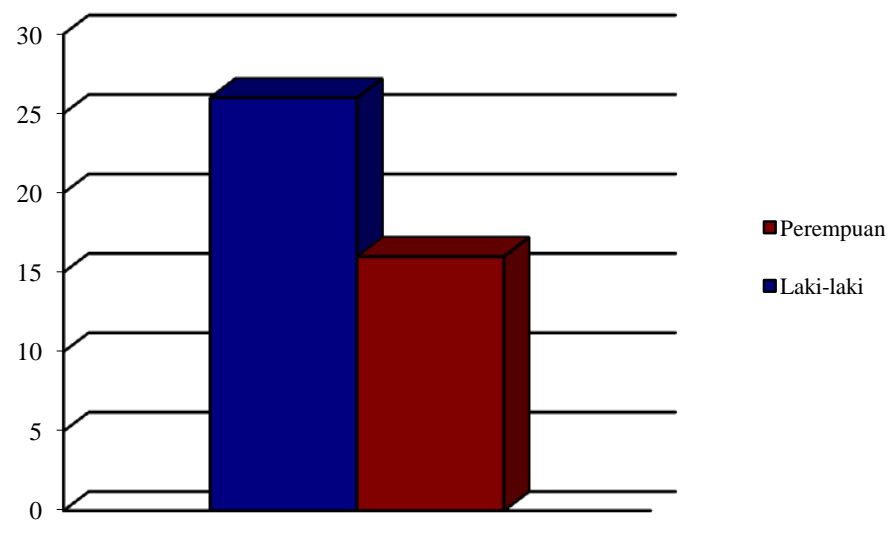

Gambar 1. Distribusi Jenis Kelamin Penderita Diare Pada Pasien Pediatrik yang Menggunakan Antibiotik di Instalasi Rawat Inap RSUD Abdul Wahab Sjahranie Samarinda

Laki-laki lebih rentan terhadap infeksi yang disebabkan oleh parasit, dimana umumnya laki-laki menunjukkan penurunan respon imun dan peningkatan intensitas infeksi dibandingkan perempuan. Perbedaan ini berkaitan dengan faktor fisiologis seperti hormonal (Klein , 2000). Menurut Santrock (2003), adanya hormon estrogen pada perempuan memperkuat sistem kekebalan tubuh, membuat perempuan lebih tahan terhadap infeksi. Hormon estrogen pada perempuan mempengaruhi sintesis IgG dan IgA menjadi lebih meningkat, dimana peningkatan tersebut yang membuat perempuan kebal terhadap infeksi (Radji, 2010).

Tabel 2. Distribusi Usia Penderita Diare Pada Pasien Pediatrik yang Menggunakan Antibiotik di Instalasi Rawat Inap RSUD Abdul Wahab Sjahranie Samarinda

\begin{tabular}{ccc}
\hline Usia & Jumlah & Persentase \\
\hline $\begin{array}{c}\text { 0-27 hari } \\
\text { (new born) }\end{array}$ & 0 & $0 \%$ \\
$1-23$ bulan \\
(infant dan toddler) \\
2- 6 tahun \\
(pra sekolah) \\
$\begin{array}{c}\text { 6-12 tahun } \\
\text { (usia sekolah) }\end{array}$ & 25 & $59,52 \%$ \\
$12-16$ tahun \\
(remaja)
\end{tabular}




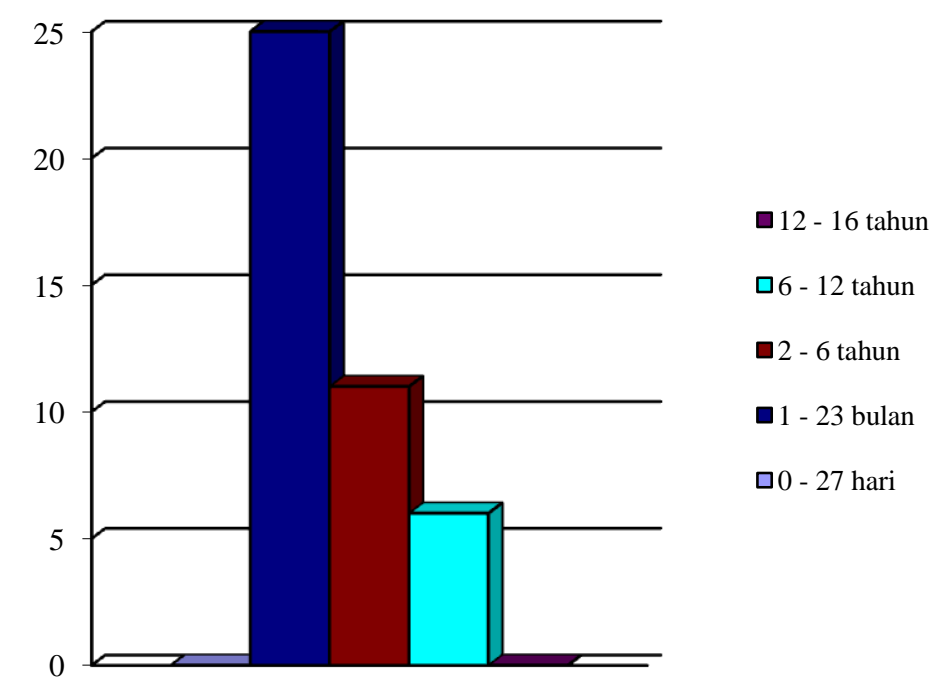

Gambar 2. Distribusi Usia Penderita Diare Pada Pasien Pediatrik yang Menggunakan Antibiotik di Instalasi Rawat Inap RSUD Abdul Wahab Sjahranie Samarinda

Distribusi penderita diare pada pasien pediatrik yang menggunakan antibiotik berdasarkan usia (Tabel 2), diketahui jumlah penderita yang berusia 1-23 bulan menunjukkan persentase terbesar yaitu $59,52 \%$ ( 25 penderita), diikuti berturut-turut berusia 2-6 tahun 26,20\% (11 penderita) dan 6-12 tahun (6 penderita). Sementara persentase penderita diare untuk usia 0 -27 hari dan 12-16 tahun adalah 0\%, karena tidak ada penderita diare pada pasien pediatrik yang dirawat inap pada usia tersebut. Menurut Departemen Kesehatan Republik Indonesia (2000), kejadian diare meningkat sejak usia 6 bulan dan mencapai puncaknya pada usia 1-2 tahun.

Pada saat bayi berusia lebih dari 6 bulan, pemberian makanan pendamping ASI (MPASI) mulai diberikan. Pada usia ini bayi secara bertahap mulai dibiasakan dengan makanan orang dewasa dimana hal tersebut dapat beresiko terhadap kesehatan anak terutama pada sistem pencernaannya. Disamping itu, makanan sudah terkontaminasi oleh mikroorganisme patogen penyebab diare akibat cara pengolahan dan penyajian makanan yang kurang higiene (Departemen Kesehatan Republik Indonesia, 2001).

Tabel 3. Distribusi Penderita Diare Pada Pasien Pediatrik Berdasarkan Pendidikan Orang Tua di Instalasi Rawat Inap RSUD Abdul Wahab Sjahranie Samarinda

\begin{tabular}{ccc}
\hline Pendidikan Orang Tua & Jumlah & Presentase \\
\hline SD & 3 & $7.14 \%$ \\
SLTP & 5 & $11.90 \%$ \\
SLTA & 20 & $47.62 \%$ \\
Sarjana & 1 & $2.38 \%$ \\
Tanpa keterangan & 13 & $30.95 \%$ \\
\hline Total & $\mathbf{4 2}$ & $\mathbf{1 0 0 \%}$ \\
\hline
\end{tabular}




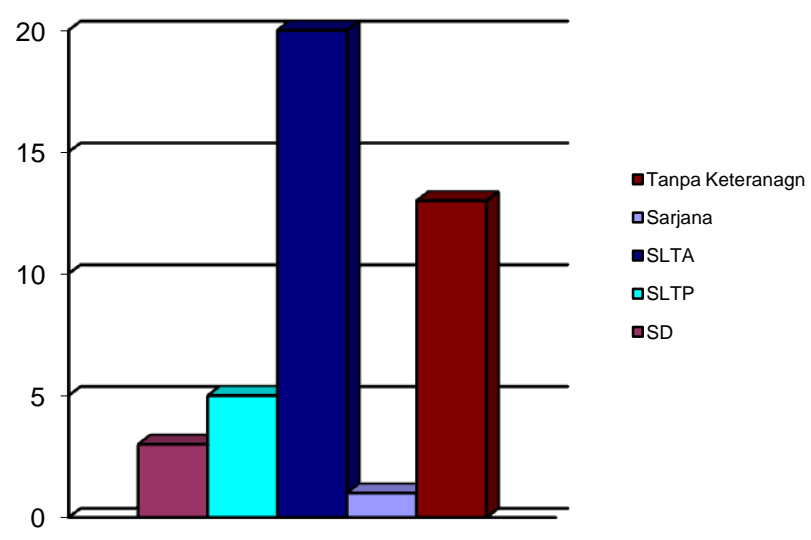

Gambar 3. Distribusi Penderita Diare Pada Pasien Pediatrik Berdasarkan Pendidikan Orang Tua di Instalasi Rawat Inap RSUD Abdul Wahab Sjahranie Samarinda

Penderita diare pada pasien pediatrik di instalasi rawat inap RSUD Abdul Wahab Sjahranie paling banyak diderita pada pasien dengan pendidikan terakhir orang tua pasien adalah SLTA dengan persentase sebesar 47,62\% (20 penderita), SLTP 11,90\% (5 penderita), SD 7,14\% (3 penderita) dan Sarjana 2,38\% (1 penderita) serta tanpa keterangan $30,95 \%$ (13 penderita) (Tabel 3).

Tabel 4. Distribusi Penderita Diare Pada Pasien Pediatrik Berdasarkan Pekerjaan Orang Tua di Instalasi Rawat Inap RSUD Abdul Wahab Sjahranie Samarinda

\begin{tabular}{ccc}
\hline Pekerjaan Orang Tua & Jumlah & Presentase \\
\hline PNS & 1 & $2.38 \%$ \\
Pegawai Swasta & 24 & $57.14 \%$ \\
Wiraswasta & 2 & $4.76 \%$ \\
Buruh & 2 & $4.76 \%$ \\
Tanpa Keterangan & 13 & $30.95 \%$ \\
\hline Total & $\mathbf{4 2}$ & $\mathbf{1 0 0 \%}$ \\
\hline
\end{tabular}

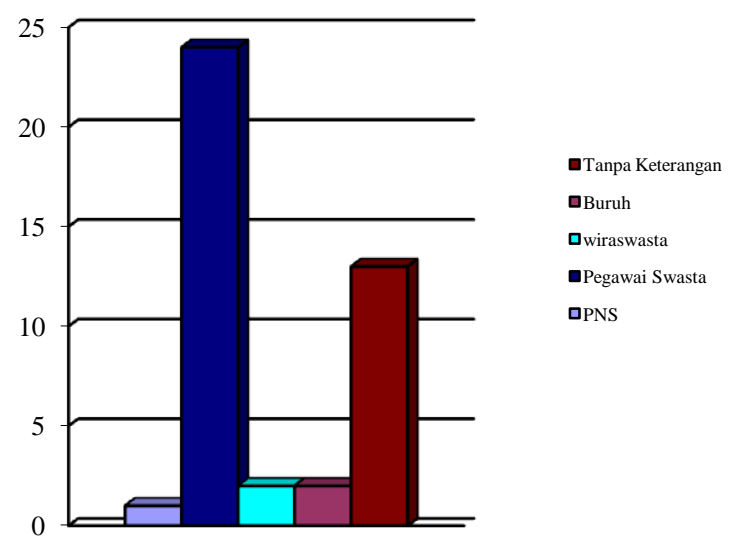

Gambar 4. Distribusi Penderita Diare Pada Pasien Pediatrik Berdasarkan Pekerjaan Orang Tua di Instalasi Rawat Inap RSUD Abdul Wahab Sjahranie Samarinda 
Berdasarkan pekerjaan orang tua paling banyak terjadi pada pasien dengan pekerjaan orang tua adalah pegawai swasta dengan persentase sebesar $57,14 \%$ ( 24 penderita), wiraswasta dan buruh dengan persentase yang sama masing-masing 4,76\% (2 penderita), PNS 2,38\% (1 penderita), serta tanpa keterangan 30,95\% (13 penderita) (Tabel 4).

Pada Tabel 6, penderita diare pada pasien pediatrik paling banyak menggunakan antibiotik golongan sefalsosporin generasi ketiga $(55,32 \%)$ dan penisilin $(21,27 \%)$. Kedua golongan antibiotik ini merupakan broad spectrum yang memiliki aktifitas baik terhadap bakteri Gram negatif maupun bakteri Gram positif (Resse, 2000).

Sefalosporin memiliki spektrum aktivitas antrimikroba yang sama luas dan efek samping yang lebih kecil daripada fluoroquinolon, sehingga digunakan sebagai obat terbaik untuk pengobatan empiris pada diare akut karena infeksi yang terjadi pada anakanak. Antibiotik golongan sefalosporin yang utama digunakan adalah seftriakson. Seftriakson memiliki tingkat keberhasilan yang sama dengan fluoroqunolon dimana kedua antibiotik tersebut efektif untuk pengobatan Shigellosis. Kelemahan dari penggunaan seftriakson sebagai terapi empiris untuk pada diare akut yang dikarenankan infeksi pada anak-anak adalah dapat meningkatkan bahaya resitensi mikroba terhadap antibiotik tersebut (Daniel, 2006).

Tabel 5. Distribusi Jenis Antibiotik dan Golongan Antibiotik yang Digunakan Penderita Diare pada Pasien Pediatrik di Instalasi Rawat Inap RSUD Abdul Wahab Sjahranie Samarinda

\begin{tabular}{ccccc}
\hline \multirow{2}{*}{ Jenis Antibiotik } & \multirow{2}{*}{ Golongan Antibiotik } & \multirow{2}{*}{ Jumlah } & \multicolumn{2}{c}{ Persentase } \\
\cline { 3 - 5 } & & & Jenis AB & Gol. AB \\
\hline Amikacin & Aminoglikosida & 1 & $2.13 \%$ & $2.13 \%$ \\
Ampicillin & Penicillin & 10 & $21.27 \%$ & $21.27 \%$ \\
Cefotaxime & Cephalosporin & 16 & $34.04 \%$ & $55.32 \%$ \\
Ceftriaxone & Polymyxin & 10 & $21.27 \%$ & $2.13 \%$ \\
Colistin & Sulfonamida & 7 & $14.89 \%$ & $14.89 \%$ \\
Cotrimoxazole & Karbapenem & 1 & $2.13 \%$ & $2.13 \%$ \\
Meropenem & Nitroimidazole & 1 & $2.13 \%$ & $2.13 \%$ \\
Metronidazole & & $\mathbf{4 8}$ & \multicolumn{3}{c}{$\mathbf{1 0 0 \%}$} \\
\hline Total & & \multicolumn{3}{c}{}
\end{tabular}

Dinding sel bakteri terdiri dari suatu jaringan peptidoglikan, yaitu polimer dari senyawa amino dan gula yang saling terikat satu dengan yang lain dan dengan demikian memberikan kekuatan mekanisme pada dinding. Penisilin dan sefalosporin menghalangi sintesa lengkap dari polimer yang spesifik bagi kuman yang disebut murein. Bila sel tumbuh dan plasma murein bertambah atau menyerap air dengan jalan osmosis, maka dinding sel akan pecah dan bakteri musnah. Dinding sel manusia tidak terdiri dari murein, sehingga antibiotik ini tidak toksik untuk manusia (Tjay dan Rahardja, 2007). 


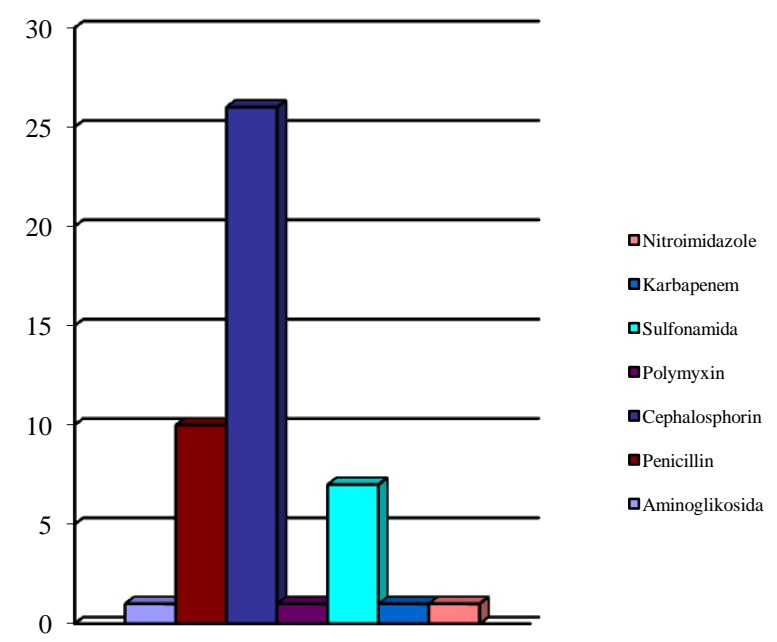

Gambar 5. Distribusi Golongan Antibiotik yang Digunakan Penderita Diare pada Pasien Pediatrik di Instalasi Rawat Inap RSUD Abdul Wahab Sjahranie Samarinda

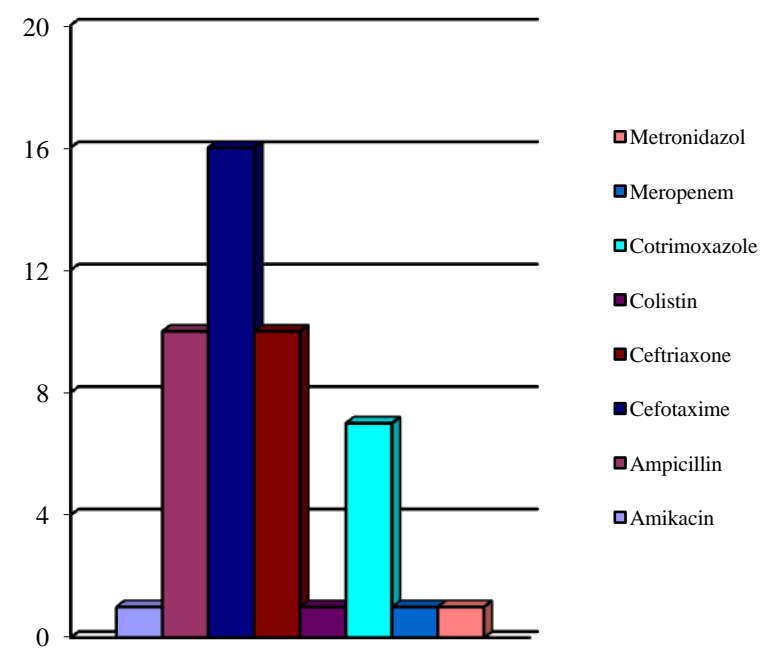

Gambar 6. Distribusi Jenis Antibiotik yang Digunakan Penderita Diare pada Pasien Pediatrik di Instalasi Rawat Inap RSUD Abdul Wahab Sjahranie Samarinda

Dari diagram di atas diketahui antibiotik paling banyak digunakan untuk terapi pengobatan diare pada pasien pediatrik adalah golongan sefalosporin generasi ketiga yaitu sefotaksim $(34,04 \%)$. Sefotaksim merupakan antibiotik golongan sefalosporin generasi ketiga yang memiliki aktifitas yang kuat terhadap bakteri Gram negatif dan lebih tahan terhadap laktamase atau beta laktam. Antibiotik ini efektif terhadap spesies bakteri yang sudah kebal terhadap sefalosporin generasi sebelumnya dan untuk golongan antibiotik lainnya. Sefotaksim lebih dipilih untuk anak-anak terutama neonatus daripada seftriakson karena tidak mempengaruhi metabolisme bilirubin sebagaimana seftriakson (Resse, 2000).

Rute pemberian antibiotik penderita diare pada pasien pediatrik paling banyak diberikan melalui rute intravena. Hal ini dikarenakan ada beberapa antibiotik yang tidak 
dapat diserap di saluran GI sehingga harus diberikan melalui rute intravena dan intramuskular, seperti antibiotik golongan sefalosporin. Pada penelitian ini antibiotik yang paling banyak digunakan adalah golongan sefalosporin generasi ketiga yaitu sefotaksim dan rute pemberian dari antibiotik tersebut adalah secara intravena.

Tabel 6. Distribusi Pola Penggunaan Antibiotik Penderita Diare pada Pasien Pediatrik Berdasarkan Rute Pemberian di Instalasi Rawat Inap RSUD Abdul Wahab Sjahranie Samarinda

\begin{tabular}{ccc}
\hline Rute Pemberian & Jumlah & Presentase \\
\hline Intravena & 41 & $85.42 \%$ \\
Oral & 7 & $14.58 \%$ \\
\hline Total & $\mathbf{4 8}$ & $\mathbf{1 0 0 \%}$ \\
\hline
\end{tabular}

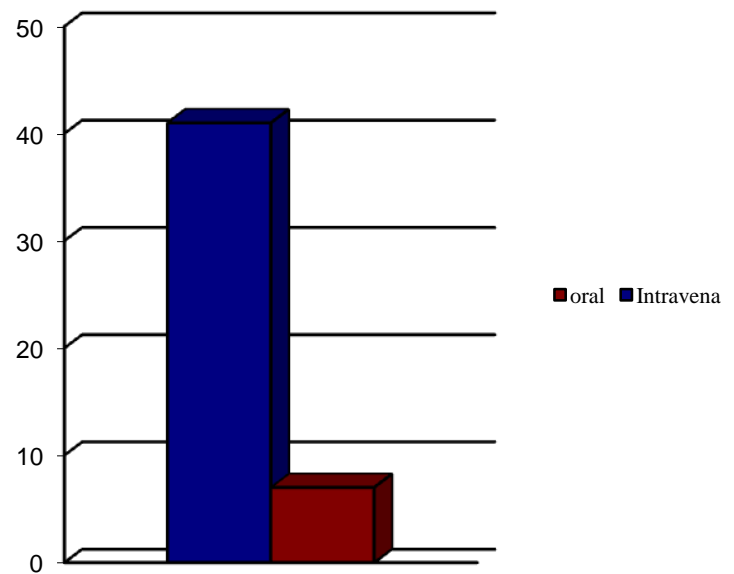

Gambar 7. Distribusi Pola Penggunaan Antibiotik Penderita Diare pada Pasien Pediatrik Berdasarkan Rute Pemberian di Instalasi Rawat Inap RSUD Abdul Wahab Sjahranie Samarinda

Tabel 7. Distribusi Pola Penggunaan Antibiotik Penderita Diare pada Pasien Pediatrik Berdasarkan Lama Pemberian di Instalasi Rawat Inap RSUD Abdul Wahab Sjahranie Samarinda

\begin{tabular}{ccc}
\hline Lama Pemberian (hari) & Jumlah & Presentase \\
\hline 2 & 13 & $27,10 \%$ \\
3 & 15 & $31,25 \%$ \\
4 & 7 & $14,58 \%$ \\
5 & 7 & $14,58 \%$ \\
7 & 3 & $6,25 \%$ \\
8 & 1 & $2,08 \%$ \\
10 & 1 & $2,08 \%$ \\
12 & 1 & $2,08 \%$ \\
\hline Total & $\mathbf{4 8}$ & $\mathbf{1 0 0 \%}$ \\
\hline
\end{tabular}




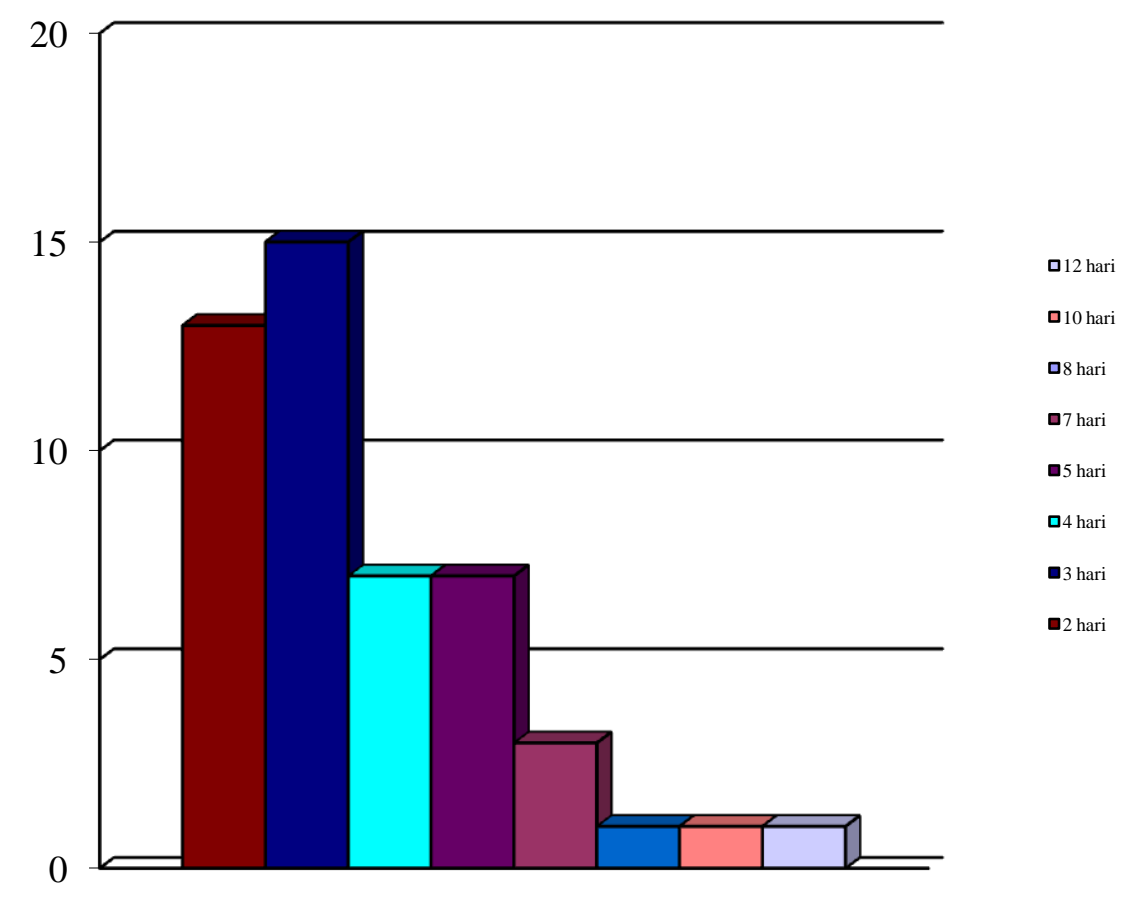

Gambar 8. Distribusi Pola Penggunaan Antibiotik Penderita Diare pada Pasien Pediatrik Berdasarkan Lama Pemberian di Instalasi Rawat Inap RSUD Abdul Wahab Sjahranie Samarinda

Dari tabel dan diagram di atas diketahu lama pemberian antibiotik dengan jumlah terbanyak adalah selama 3 hari dengan persentase sebesar 31,25\%. Menurut Buku Bagan Manajemen Terpadu Balita Sakit (MTBS) Indonesia yang dikeluarkan oleh Depatemen Kesehatan Republik Indonesia, lama penggunaan antibiotik minimnal 5 hari untuk menghindari terjadinya resistensi. Tetapi pada umumnya lama penggunaan antibiotik 3-5 hari masih diperbolehkan. Pada prinsipnya lama penggunaan antibiotik bergantung pada tipe dan keparahan infeksi dan seharusnya ditentukan oleh respon klinis dan bakteriologik pada pasien (Departemen Kesehatan Republik Indonesia, 2001).

Berdasarkan tabel 9 diketahui kesesuaian dosis antibiotik untuk penderita diare pada pasien pediatrik $92,85 \%$ telah sesuai. Dosis yang diberikan kepada pasien masih dalam dosis antara dosis lazim dengan dosis maksimumnya. Pemberian dosis antibiotik amikasin, ampisilin, sefotaksim, kortimokasasol, colistin dan metrosnidasol telah sesuai dosis pemberiannya, sedangkan pemberian doiss antibiotik seftriakson dan meropenem ada beberapa yang tidak sesuai, dimana beberapa dosis yang diberikan melebihi dosis maksimum dari antibiotik tersebut. Dosis seftriakson dan meropenem yang diberikan adalah $600 \mathrm{mg} 3 \times 1$ dan $255 \mathrm{mg} 3 \times 1$, sementara dosis maksimum dari seftriakson adalah 1 g/hari sedangkan meropenem adalah $120 \mathrm{mg} / \mathrm{kg} 3 \times 1$ (WHO, 2010). 
Tabel 9. Distribusi Pola Penggunaan Antibiotik Penderita Diare pada Pasien Pediatrik Berdasarkan Kesesuain Dosis di Instalasi Rawat Inap RSUD Abdul Wahab Sjahranie Samarinda Periode Desember 2015 - Maret 2016

\begin{tabular}{|c|c|c|c|c|c|}
\hline $\begin{array}{c}\text { Nama } \\
\text { Antibiotik }\end{array}$ & $\begin{array}{l}\text { Bentuk } \\
\text { Sediaan }\end{array}$ & Usia & Dosis Pasien (mg) & $\begin{array}{c}\text { Dosis } \\
\text { Maksimum }\end{array}$ & $\begin{array}{c}\% \\
\text { Kesesuaian }\end{array}$ \\
\hline Amikasin & IV & 4 tahun & $150 \mathrm{mg} 1 \times 1$ & $1 \mathrm{~g}$ & 100 \\
\hline \multirow{8}{*}{ Ampiciliin } & IV & 2 bulan & $125 \mathrm{mg} 4 \times 1$ & \multirow{8}{*}{$2 \mathrm{~g} / 4 \mathrm{jam}$} & 100 \\
\hline & \multirow{2}{*}{ IV } & \multirow{2}{*}{3 bulan } & $100 \mathrm{mg} 3 \times 1$ & & 100 \\
\hline & & & $150 \mathrm{mg} 4 \times 1$ & & 100 \\
\hline & IV & 10 bulan & $200 \mathrm{mg} 2 \times 1$ & & 100 \\
\hline & \multirow{2}{*}{ IV } & \multirow{2}{*}{1 tahun } & $150 \mathrm{mg} 4 \times 1$ & & 100 \\
\hline & & & $300 \mathrm{mg} 3 \times 1$ & & 100 \\
\hline & IV & 5 tahun & $500 \mathrm{mg} 4 \times 1$ & & 100 \\
\hline & IV & 7 tahun & $700 \mathrm{mg} 3 \times 1$ & & 100 \\
\hline \multirow{12}{*}{ Cefotaxime } & IV & 2 bulan & $175 \mathrm{mg} 4 \times 1$ & \multirow{12}{*}{$12 \mathrm{~g} / \mathrm{hari}$} & 100 \\
\hline & IV & 5 bulan & $210 \mathrm{mg} 3 \times 1$ & & 100 \\
\hline & \multirow{2}{*}{ IV } & \multirow{2}{*}{9 bulan } & $150 \mathrm{mg} 4 \times 1$ & & 100 \\
\hline & & & $200 \mathrm{mg} 3 \times 1$ & & 100 \\
\hline & IV & 10 bulan & $250 \mathrm{mg} 3 \times 1$ & & 100 \\
\hline & IV & & $250 \mathrm{mg} 3 \times 1$ & & 100 \\
\hline & IV & 1 tahun & $300 \mathrm{mg} 3 \times 1$ & & 100 \\
\hline & IV & 2 tahun & $300 \mathrm{mg} 3 \times 1$ & & 100 \\
\hline & IV & \multirow{2}{*}{3 tahun } & $500 \mathrm{mg} 3 \times 1$ & & 100 \\
\hline & IV & & $400 \mathrm{mg} 3 \times 1$ & & 100 \\
\hline & IV & 6 tahun & $600 \mathrm{mg} 3 \times 1$ & & 100 \\
\hline & IV & 7 tahun & $300 \mathrm{mg} 3 \times 1$ & & 100 \\
\hline \multirow{7}{*}{ Ceftriaxone } & IV & 9 bulan & $250 \mathrm{mg} 2 \times 1$ & \multirow{7}{*}{$1 \mathrm{~g} /$ hari } & 100 \\
\hline & IV & \multirow{2}{*}{1 tahun } & $350 \mathrm{mg} 2 \times 1$ & & 100 \\
\hline & IV & & $400 \mathrm{mg} 2 \times 1$ & & 100 \\
\hline & IV & \multirow{2}{*}{2 tahun } & $300 \mathrm{mg} 3 \times 1$ & & 100 \\
\hline & IV & & $600 \mathrm{mg} 3 \times 1$ & & 0 \\
\hline & IV & \multirow{2}{*}{4 tahun } & $600 \mathrm{mg} 2 \times 1$ & & 0 \\
\hline & IV & & $500 \mathrm{mg} 2 \times 1$ & & 100 \\
\hline \multirow{7}{*}{ Cotrimoxazole } & $\mathrm{PO}$ & 8 bulan & $3 / 4$ cth $2 \times 1$ & \multirow{7}{*}{$160 \mathrm{mg} / \mathrm{kg} 2 \times 1$} & 100 \\
\hline & $\mathrm{PO}$ & \multirow{4}{*}{1 tahun } & $3 / 4$ cth $2 \times 1$ & & 100 \\
\hline & $\mathrm{PO}$ & & $3 / 4$ cth $2 \times 1$ & & 100 \\
\hline & $\mathrm{PO}$ & & 1 cth $2 \times 1$ & & 100 \\
\hline & IV & & $1 \mathrm{mg} 3 \times 1$ & & 100 \\
\hline & $\mathrm{PO}$ & 2 tahun & 1 cth $2 \times 1$ & & 100 \\
\hline & $\mathrm{PO}$ & 7 tahun & 1 cth $2 \times 1$ & & 100 \\
\hline Colistin & IV & 4 bulan & $150000 \mathrm{IU} / \mathrm{kg} 3 \times 1$ & $5 \mathrm{mg} / \mathrm{kg} / \mathrm{hari}$ & 100 \\
\hline Meropenem & IV & 5 bulan & $255 \mathrm{mg} 3 \times 1$ & $120 \mathrm{mg} / \mathrm{kg} 3 \times 1$ & 0 \\
\hline Metronidazole & IV & 5 bulan & $64 \mathrm{mg} 3 \times 1$ & $500 \mathrm{mg}$ & 100 \\
\hline \multicolumn{5}{|l|}{ Total } & $92,85 \%$ \\
\hline
\end{tabular}




\section{KESIMPULAN}

Berdasarkan hasil penelitian, analisis dan pembahasan maka dapat disimpulakan:

1. Karakteristik penderita diare pada pasien pediatrik di Instalasi Rawat Inap RSUD Abdul Wahab Sjahranie Samarinda: 61,90\% berjenis kelamin laki-laki; 38,10\% berjenis kelamin perempuan; usia 1-23 bulan 59,52\%; tingkat pendidikan terakhir orang tua adalah SLTA $47,62 \%$; dan pekerjaan orang tua adalah pegawai swasta $57,14 \%$.

2. Antibiotik yang paling banyak digunakan penderita diare pada pasien pediatrik adalah golongan sefalosporin generasi ketiga yaitu (sefotaksim) 34,04\%, rute pemberian secara intravena $85,42 \%$, lama pemberian antibiotik selama 3 hari $31,25 \%$, dan dosis pemberian antibiotik $92,85 \%$ telah sesuai.

\section{DAFTAR PUSTAKA}

1 Badan Penelitian dan Pengembangan Kesehatan Departemen Kesehatan Republik Indonesia. 2009. Riset Kesehatan Dasar Provinsi Kalimantan Timur Tahun 2007. Departemen Kesehatan Republik Indonesia: Jakarta.

2. Cakrawardi, Wahyudin. E., dan Sarrudin. B. 2009. Pola Penggunaan Antibiotik Pada Gastroenteritis Berdampak Diare Akut Pasien Anak Rawat Inap di Badan Layanan Umum Rumah Sakit Dr. Wahidin Sudirohusodo Makassar. Majalah Farmasi dan Farmakologi Volume 15 Nomor 2.

3. Daniel. R., Diniz-Santos., Luciana. R., Silva dan Nanci. S. 2006. Antibiotik for Treatment of Acute Infection Diarrhea in Children. The Brazilian Journal of Infectious Diseases Volume 10.

4. Darmansjah. I. 2008. Penggunaan Antibiotik pada Pasien Anak. Majalah Kedokteran Indonesia Volume 58 Nomor 10.

5. Departemen Kesehatan Republik Indonesia. 2000. Buku Pedoman Pelaksanaan Pemberantasan Penyakit Diare. Departemen Kesehatan Republik Indonesia: Jakarta.

6. Departemen Kesehatan Republik Indonesia. 2001. Buku Pedoman Pelaksanaan Program Diare. Ditjen PPM dan PLP: Jakarta.

7. Departemen Kesehatan Republik Indonesia. 2001. Buku Bagan Menejemen Terpadu Balita Sakit (MTBS) Indonesia. Departemen Kesehatan Republik Indonesia: Jakarta.

8. Dinas Kesehatan Provinsi Kalimantan Timur. 2013. Profil Kesehatan Provinsi Kalimantan Timur Tahun 2013. Dinas Kesehatan Provinsi Kalimantan Timur: Kalimantan Timur.

9. Gauthier. P., dan Cardot. J. M. 2011. Developing Drugs fir Children and The Adjustment of Medicine. Peronalized Medicine Volume 1.

10. Juffrie. M. 2009. Buku Ajar Gastroenterologi-Hepatologi Jilid 1. Ikatan Dokter Anak Indonesia: Jakarta.

11. Klein. S. L. 2000. Hormones and Mating System Affect Sex and Species Differences in Immune Function Among Vertebrates. Behavioural Processes Volume 51 Nomor 1-3, halaman 149-166.

12. Neal dan Michael. J. 2006. Medical Pharmacology At Glance Edisi 5. Penerbit Erlangga: Jakarta.

13. Poerwati. E. 2013. Determinan Lama Rawat Inap Pasien Balita dengan Diare. Jurnal Kedokteran Brawijaya Volume 27 Nomor 4.

14. Radji .M. 2010. Human Immunodeficiency Virus. In: Imunologi dan Virologi. PT.ISFI: Jakarta.

15. Resse R. E., Betts. R., dan Gumustop. B. 2000. Handbook of Antibiotics 3rd Ed. Lippincott Williams \& Wilkins: Philadelphia

16. Rudolph . A. M. 2003. Rudolph's Pediatrics, 21st Edition. New York: McGraw-Hill. 
17. Santrock. J. W. 2003. Adolescence Perkembangan Remaja. Erlangga: Jakarta.

18. Smith. W. J. A. 2003. Masalah Pediatri di Bidang Gastroenterologi Tropis, dalam Problem Gastroenterologi Daerah Tropis Ed GC Book, Edisi ke-1. Penerbit Buku Kedokteran EGC: Jakarta.

19. Stringer dan Janet . L. 2006. Basic Concepts in Pharmacology: a Student's Survival Guide. Edisi 3. Buku Kedokteran EGC: Jakarta. Hal. 186 - 199

20. Tjay. T. H., dan Rahardja. K. 2007. Obat-Obat Penting : Khasiat, Penggunaan dan Efek Samping Edisi Ke Enam. Gramedia: Jakarta.

21. WHO. 2010. WHO Model Formulary for Children.World Health Organitation. 